\title{
An OUtPut PERSPECTIVE ON A NortheAst Asia CURRENCY UNION
}

\author{
YIN-WONG CHEUNG \\ JUDE YUEN
}

CESIFO WORKING PAPER NO. 1250

CATEGORY 6: MONETARY POLICY AND INTERNATIONAL FINANCE

JULY 2004

Presented at CESifo Venice Summer Institute, Workshop on Monetary

UNIONS AFTER EMU, AUGUST 2003

\footnotetext{
An electronic version of the paper may be downloaded

- from the SSRN website:

www.SSRN.com

- from the CESifo website:

www. CESifo.de
} 


\title{
AN OUtPut Perspective ON A NorTheast ASIA CURRENCY UNION
}

\begin{abstract}
The prospect of creating a currency union consisting of China, Japan, and Korea is evaluated using output data. After a brief discussion on the interactions between the three countries, the study investigates whether these three countries have common synchronous business cycles, which are perceived as one of the preconditions of a currency union. Then, we assess the potential costs of giving up monetary policy autonomy to form a currency union. It is found that the three national output series tend to move together in the long run and share common business cycles. While the output loss estimates depend on assumptions used to generate shocks, they tend to be small. However, there are potential conflicts between these countries on the choice of the policy target of the common monetary authorities.
\end{abstract}

JEL Code: F33, F41.

Keywords: common stochastic trend, business cycles, output losses, exchange rate regime, Asian economies.

\author{
Yin-Wong Cheung \\ Economics Department \\ University of California \\ Santa Cruz, CA 95064 \\ $U S A$ \\ cheung@ucsc.edu
}

\author{
Jude Yuen \\ Economics Department \\ University of California \\ Santa Cruz, CA 95064 \\ USA \\ jnyuen@yahoo.com
}

The authors thank Hyungdo Ahn, Menzie Chinn, Charles Engel, Paul De Grauwe, Chang-Jae Lee, Yong Hyup Oh, Alejandro Micco, Reinhard Neck, Blanca Sanchez-Robles, Kiril Strahilov, Jose Tavares, and participants of the 2003 Venice Summer Institute Workshop on "Monetary Unions after EMU," the seminars at Cheng Kung University, The Hong Kong Institute for Monetary Research, and the Korea Institute for International Economic Policy for their comments and suggestions. Also, we thank Desmond Hou for compiling the data. The financial support of faculty research funds of the University of California, Santa Cruz is gratefully acknowledged. The views contained herein are solely those of the authors. 


\section{Introduction}

The 1997 financial crisis highlights the vulnerability of Asian countries as a group to one country's financial instability. Since then, various initiatives and plans on fostering monetary and financial cooperation in the region have been proposed to forestall financial crises. The proposals include improved dialogues, the establishment of central bank swap arrangements (the Chiang Mai Initiative), the idea of an Asian monetary fund, the possibility that currencies collectively peg to the US dollar or a basket of currencies, the creation of an Asian currency unit, and the formation of a currency union. ${ }^{1}$ These discussions generate some interests in assessing whether the Asian countries meet the preconditions of an optimum currency area and are suitable for forming a currency union. ${ }^{2}$

This paper examines the prospect of creating a currency union that consists of China, Japan, and Korea. The formation of a currency union requires deep commitments from its member countries. For instance, member countries have to relinquish their monetary autonomy to use a common single currency. Because China, Japan, and Korea are the three largest economies in East Asia, it is hard to perceive that an effective coordination scheme in the region does not involve these three countries. In Europe, the two largest countries France and Germany are usually credited for the formation of European Monetary Union and the launch of the single currency, euro. The Franco-German partnership is deemed to be pivotal for the migration towards the European currency union. ${ }^{3}$ Given the European experience, we focus the suitability of an Asian currency union that comprises China, Japan, and Korea.

The standard literature lists a few criteria for countries to constitute an optimum currency area. ${ }^{4}$ Business cycle synchronization is one of the major criteria used to evaluate the desirability of a common currency. ${ }^{5}$ When business cycles across countries are synchronous, the cost of using a single currency is reduced because there is less need for asymmetric monetary policy

\footnotetext{
$1 \quad$ See, for example, Eichengreen (2001) and Wyplosz (2002) for discussions of these proposals and the related references.

2 See, for example, Bayoumi and Mauro (1999), Eichengreen and Bayoumi (1999), Lee, Park and Shin (2002), McKinnon and Schnabl (2003), and Ng (2002).

3 See, for example, Eijffinger and Haan (2000) and De Grauwe (2000) for a detailed discussion of the European Union.

$4 \quad$ Mundell (1961) is the seminal study on optimal currency areas. Lafrance and St-Amant (1999), for example, offer a recent review of the literature on optimum currency areas.

$5 \quad$ Other criteria include the similarities of trade patterns and levels of economic development, the degree of trade and financial integration, and the mobility of labor markets.
} 
responses to common shocks, ceteris paribus. On the other hand, currency union may not be an optimal monetary arrangement when the countries display asynchronous business cycles. ${ }^{6}$

In the literature, the contemporaneous correlation of output shocks is commonly used to gauge the degree of business cycle synchronization. Several approaches have been used to derive output shocks for correlation calculation. The results, however, are sensitive to the choice of detrending methods. ${ }^{7}$ Bayoumi and Eichengreen (1994) popularize the use of the Blanchard and Quah (1989) decomposition method to measure the size and correlation of output shocks and assert that the supply shock correlation is the relevant measure to evaluate the output shock asymmetry between countries.

Contemporaneous correlation, however, does not necessarily provide a complete picture. The effects of shocks on economies crucially depend on the transmission mechanism within and across them. Divergent monetary or exchange rate policies may deem necessary even in the presence of a high correlation of shocks if the transmission mechanisms are sufficiently different across the countries. On the other hand, a low contemporaneous shock correlation does not exclude the possibility that the economies are in similar phases of a business cycle and do not require different monetary or exchange rate policies. Thus, we adopt a complementary approach and directly examine comovement patterns of national outputs.

The current exercise assesses output synchronization at both long-run and short-run horizons. First, we investigate whether the national output data tend to move together in the long run. If national output data are drifting apart in the long run, it is impracticable, if not impossible, to pursue a common policy to manage these economies. Thus, long-run output comovement is a basic condition for currency union discussion. Second, we determine whether the countries share short-run cyclical business cycles. After all, most monetary policies are devised to manage transitory shocks. If the countries under consideration share long-run growth trends and short-run economic fluctuations, then a single common currency is a feasible proposition.

The Johansen cointegration approach is used to examine the output comovement pattern. A currency union has implications for interactions between all its member countries that go beyond bilateral relationships. In contrast with the usual bilateral setting embedded in most, if not all, recent studies on currency unions, the cointegration model is a multivariate framework

\footnotetext{
$6 \quad$ McKinnon (2001) refers to Mundell (1973) and points out that, in the presence of risk sharing, asymmetric shocks may not necessarily imply currency union is not desirable.
} 
that incorporates interactions between all data series in assessing the output comovement pattern. Further, the error correction specification derived from a cointegration model provides a coherent structure to study output comovements in the long run, effects of deviations from the long-run relationship on short-run variations, and output interactions in the short run. The structure is flexible enough to accommodate various types of data dynamics in the analysis.

The presence of contemporaneous output comovement is the relevant information when countries have similar and simultaneous responses to a common shock. However, due to structural or institutional differences, countries can display different initial responses to a common shock even though they react similarly to the shock after an initial phase. Thus, in studying short-run cyclical cycles, we consider both "common feature" and "codependenc" business cycles - the former type of common business cycles requires countries to be in similar positions throughout a cycle and the latter type allows countries to behave differently in the initial phase but to be in similar cyclical phases after some initial period. The inclusion of codependent business cycles, in addition to common feature ones, alleviates the possibility of understating the degree of output symmetry between countries and the desirability of a currency union.

To offer further insight into the prospect of a currency union in Asia, we quantify the individual countries' potential output losses of establishing one. Since the ideal preconditions of a currency union are rarely fulfilled, there is always a cost for a country to relinquish policy autonomy and join a currency union. The willingness to join is undoubtedly affected by potential costs. Thus, in addition to business cycle synchronization, it is instructive to estimate the individual countries' potential costs of joining a currency union. It is expected that the output cost estimate depends on the characterization of an economy and of shocks affecting it. In this exercise, we evaluate output losses using a) the model in Ghosh and Wolf (1994) to characterize the economy, b) shocks estimated by three different techniques, and c) two policy objectives.

The remainder of the paper is organized as follows. A brief discussion of the economic interactions, including trade and investment, between the three Northeast countries is given in the next section. Section 3 offers some preliminary analyses on the real per capita GDP data from China, Japan, and Korea. Patterns of output comovement are studies in Section 4. The Johansen cointegration test is used to determine the empirical long-run relationship among the

7 See, for example, Baxter and Stockman (1989), Harvey and Jaeger (1993), and Canova (1998). 
output data and the associated error correction model is used to study the links between the longrun and short-run interactions. In the same section, we also investigate the presence of common business cycles using the common feature and codependence tests. Section 5 evaluates the output costs of forming a currency union. Using a macro model, the output losses of individual countries and of the three countries as a group are calculated under different shock-identifying schemes and policy objectives. Some concluding remarks are given in Section 6.

\section{Recent Developments}

What is the prospect of a Northeast Asia economic bloc? As recent as the turn of the millennium, China, Japan and Korea were not members of any regional economic or trade establishments. Indeed, the discussion on the integration between China, Japan, and Korea is quite recent and scant. Japan and Korea operated mostly within the framework of the General Agreement on Tariffs and Trade and the succeeding World Trade Organization, to formulate their trade policies. China, in fact, only joined the World Trade Organization in December 2001. However, the desire for improved co-ordination after the 1997 financial crisis offers an incentive for the three Northeast Asian countries - China, Japan, and Korea to co-operate and deepen integration.

Even though a currency union is unlikely to happen immediately, the prospect of enhancing integration between the three countries attracts certain interest among policymakers and think tanks. For instance, in 2001, the Japanese Cabinet Office published a study that, among other things, examined the prospect of forming a free trade area encompassing China, Japan, and Korea. ${ }^{8}$ The study suggested that, while a China-Japan-Korea free trade area offers a potentially larger economic benefit, a two-country Japan-Korea free trade area might entail a less painful adjustment process and, thus, "might be considered as a first step toward a larger free trade area."

Possibly, the Japanese Cabinet Office's inquiry on a free trade area consisting of China, Japan, and Korea was a consequence of an initiative that was proposed in November 1999 by officials from these three countries to investigate the prospects of economic cooperation. In

\footnotetext{
$8 \quad$ See Cabinet Office, Government of Japan (2001).

Some other studies on the possible China-Japan-Korea economic cooperation are Schott and Goodrich (2001), and Scollay and Gilbert (2001). Cho (2000) offers an account of the trade between China, Japan, Korea and
} 
November 2000, three research organizations - the Development Research Center of the State Council of China, the National Institute of Research Advancement of Japan, and the Korea Institute for International Economic Policy - formally launched a joint research program on "Strengthening Economic Cooperation among China, Japan and Korea." In the first three years, the joint research program focused on trade facilitation (2001), mutual investment between the three countries (2002), and finally, "Economic Effects of a Possible Free Trade Area among China, Japan and Korea" (2003). ${ }^{10}$

Table 1. China's Trade with Selected Economies (US\$ Million)

\begin{tabular}{|c|c|c|c|}
\hline & & Japan & Korea \\
\hline \multicolumn{4}{|l|}{ A. Exports } \\
\hline & 1991 & 10252 & 2179 \\
\hline & 2002 & 48483 & 15508 \\
\hline \multicolumn{4}{|l|}{ Proportion of China's Exports } \\
\hline & 1991 & 0.142 & 0.030 \\
\hline & 2002 & 0.149 & 0.048 \\
\hline \multicolumn{4}{|l|}{ Average Annual Growth Rate } \\
\hline & $91-02$ & 13.85 & 57.06 \\
\hline \multicolumn{4}{|l|}{ B. Imports } \\
\hline & 1991 & 10032 & 1066 \\
\hline & 2002 & 53489 & 28581 \\
\hline \multicolumn{4}{|l|}{ Proportion of China's Imports } \\
\hline & 1991 & 0.157 & 0.017 \\
\hline & 2002 & 0.181 & 0.097 \\
\hline \multicolumn{4}{|l|}{ Average Annual Growth Rate } \\
\hline & $91-02$ & 14.41 & 62.55 \\
\hline \multicolumn{4}{|l|}{ C. Total Trade with China } \\
\hline & 1991 & 20284 & 3245 \\
\hline & 2002 & 101972 & 44089 \\
\hline \multicolumn{4}{|l|}{ Proportion of China's Trade } \\
\hline & 1991 & 0.149 & 0.024 \\
\hline & 2002 & 0.164 & 0.071 \\
\hline \multicolumn{4}{|l|}{ Average Annual Growth Rate } \\
\hline & $91-02$ & 13.69 & 57.92 \\
\hline
\end{tabular}

Southeast Asia countries in the pre-modern time. Nam (2003) provides a detailed account of trade between China and APEC economies.

${ }_{10} \quad$ See National Institute for Research Advancement of Japan (2002). 
Note: Panel A gives China's exports to Japan and Korea. It also gives these exports as proportions of China's total exports and the average annual growth rates of these exports. Similar information for imports and for total trade is provided in Panel B and Panel C.

The pace of integration between China, Japan, and Korea is quite fast in the recent years. Specifically, the volume of trade between these three countries has experienced astonishing growth along with, albeit slowly, changes in institutional arrangements. With China's WTO accession, further integration is widely anticipated.

As evidenced in Table 1, the trade between China, Japan, and Korea increased at a rate faster than the world trade. ${ }^{11}$ During the last decade, the average annual growth rate of the bilateral trade is $14 \%$ between China and Japan and is $58 \%$ between China and Korea. On the other hand, the world trade grew at an average annual rate of 5.68\% from 1991 to 2002. Indeed, the trade volume between China and these two countries was quite non-trivial - the total trade between China and these two countries accounted for $1.16 \%$ of world trade in 2002 . If the trade between Japan and Korea is included, then the trade among these three countries accounted for $1.45 \%$ of world trade.

After normalizing their diplomatic relationship in 1992, Korea and China has enjoyed a rapid growth in bilateral trade - the average annual growth rate exceeded $57 \%$. Indeed China overtook the US as Korea's largest export market in 2003. Japan, on the other hand, was China's large trading partner and accounted for $16.4 \%$ of China's trade in 2002 . The figures underscore the trading intensity between the three Northeast Asian countries. Indeed, China traded more with the other two Northeast Asian countries than with the other two Greater China economies namely Hong Kong and Taiwan.

The Japanese and Korean foreign direct investments in China were presented in Table 2. Again, the Japanese and Korean investments in China increased quite substantially between 1991 and 2002. The average growth rate of investment in China is $23 \%$ for Japan and $48 \%$ for Korea. If one excludes Hong Kong and Taiwan, which are known to provide the lion share of foreign direct investment in China, Japan and Korea are two main foreign investors in China.

11 The trade data in the table, as those in the other tables, were based on Chinese sources. It is well known trade that data from different national sources differ from each other. However, our discussion is not qualitatively affected by these differences. 
Table 2. $\quad$ Foreign Direct Investment Inflow to China (US\$ Million)

\begin{tabular}{lccc}
\hline & & Korea & Japan \\
\hline Inflow to China & 1991 & $119^{*}$ & 533 \\
& 2002 & 2721 & 4190 \\
Proportion of China's FDI & & & 0.12 \\
& 1991 & $0.01^{*}$ & 0.08 \\
Average Annual Growth Rate & 2002 & 0.05 & 23.14 \\
\hline
\end{tabular}

Note: The table gives the foreign direct investment from Japan and Korea to China. "*" is the 1992 figure and "+" is the 1993-2002 figure.

Both Tables 1 and 2 suggest that China, Japan, and Korea have extensive trade and investment interactions. The trend is likely to persist in the near future. The extensive interaction between these countries provides a good foundation for advancing integration to a higher level.

\section{Data and Preliminary Analyses}

The data considered in this study are quarterly real per capita GDPs of China, Japan, and Korea. The data are seasonally adjusted and expressed in logarithms. The sample period is from 1993:IV to 2001:IV. The sample is selected according to the liberalization processes in China and Korea. Specifically, China had a substantially controlled economy before the early 1990s. Extending the data series backwards would not yield more information relevant to assessing output integration. The data are retrieved from the CEIC and International Financial Statistics databases. For brevity, the quarterly real per capita GDP data are referred to as GDP or output data henceforth.

As a preliminary analysis, the augmented Dickey-Fuller (ADF) test for a unit root is performed on individual output series. The ADF test is based on the regression equation,

$$
\Delta X_{i t}=c_{i}+\tau_{i} t+\delta_{i} X_{i t-1}+\sum_{j=1}^{p} \alpha_{i j} \Delta X_{i t-j}+u_{i t}
$$


where $X_{i t}$ is the country i's GDP at time $t$ for $i=$ China, Japan, and Korea. Under the unit-root hypothesis, $\delta_{i}=0$. A trend or a constant or both are included if they are significant in the ADF test. The lag parameter $(p)$ is chosen to eliminate serial correlation in the estimated residuals.

The unit root test results of the GDP series and their first differences are reported in Table 3. The null hypothesis of a unit root is not rejected by GDP data themselves but is rejected by their first differences. That is, the three output series are difference stationary. The diagnostic Qstatistics indicate that the lag specifications are appropriate, and there is no evidence of serial correlation in the estimated residuals. The inference is consistent with the conventional findings that real per capita GDP data series are unit root processes. Hereafter, we treat the GDP series as I(1) processes.

Table 3. Augmented Dickey-Fuller Test Results

\begin{tabular}{|c|c|c|c|c|}
\hline & \multicolumn{2}{|c|}{ Levels } & \multicolumn{2}{|c|}{ First Differences } \\
\hline & Test Statistic (lags) & $\mathrm{Q}(4) ; \mathrm{Q}(8)$ & Test Statistic (lags) & $\mathrm{Q}(4) ; \mathrm{Q}(8)$ \\
\hline China & $-2.08(4)$ & $2.67 ; 8.87$ & $-8.54 *(3)$ & $4.39 ; 9.04$ \\
\hline Japan & $-1.56(3)$ & $0.09,7.52$ & $-5.14 *(2)$ & $0.08 ; 5.67$ \\
\hline Korea & $-2.09(1)$ & $2.70 ; 9.61$ & $-2.49 *(1)$ & $2.44 ; 4.02$ \\
\hline
\end{tabular}

Note: The results of applying the augmented Dickey-Fuller test to the national real per capita GDP data are reported. Lags are selected to remove serial correlation in the estimated residuals and are given in parentheses next to the test statistics. The Box-Ljung statistics based on the first four and first eight serial correlations of the estimated residuals are given under the heading " $\mathrm{Q}(4)$ and $\mathrm{Q}(8)$." All the reported Q-statistics are not significant. “*” indicates significance at the 5\% level (Cheung and Lai, 1995).

\section{Common Long-Run and Short-Run Cycles}

The I(1) non-stationary property suggests that individual output series tend to drift around without an anchor or steady state. If these output series drift in different directions, then it will be difficult to adopt a common currency and pursue a common monetary policy to manage these economies. In the following subsection, the Johansen (1991) cointegration test is used to test whether these I(1) output series move together in the long run or, technically speaking, whether they have common stochastic trends. 


\subsection{Common Stochastic Trends}

The Johansen cointegration test is conducted as follows. Let $\mathbf{X}_{\mathbf{t}}$ be the nxl vector containing the three output series (that is, $\mathrm{n}=3$ ), which can be modeled by a $(\mathrm{p}+1)$-th order vector autoregression process:

$$
\mathbf{X}_{t}=\mu+\sum_{i=1}^{p+1} \gamma_{i} \mathbf{X}_{t-i}+\varepsilon_{t},
$$

where $\mu$ is the intercept term and $\varepsilon_{t}$ is the vector of innovations. The lag parameter, $p$, is chosen to set the serial correlation of resulting residuals to zero. The Johansen test statistics are devised from the sample canonical correlations between $\Delta \mathbf{X}_{t}$ and $\mathbf{X}_{t-p}$, adjusting for all intervening lags. To implement the procedure, we first obtain the least squares residuals from

$$
\Delta \mathbf{X}_{t}=\mu_{1}+\sum_{i=1}^{p} \Gamma_{i} \Delta \mathbf{X}_{t-i}+\varepsilon_{1 t},
$$

and

$$
\mathbf{X}_{t-p}=\mu_{2}+\sum_{i=1}^{p} \Gamma_{i} \Delta \mathbf{X}_{t-i}+\varepsilon_{2 t},
$$

where $\mu_{1}$ and $\mu_{2}$ are constant vectors. Next, we define the matrices $\Omega_{i j}=T^{-1} \sum_{t} \hat{\varepsilon}_{i t} \hat{\varepsilon}_{j t}^{\prime}$ for $\mathrm{i}, \mathrm{j}$ $=1,2$ and $T$ is the sample size. The Johansen test is based on the eigenvalues, $\lambda_{1} \geq \ldots \geq \lambda_{\mathrm{n}}$, of $\Omega_{21} \Omega_{11}^{-1} \Omega_{12}$ with respect to $\Omega_{22}$. $\lambda_{\mathrm{i}}$ 's are the squared canonical correlations between $\Delta \mathbf{X}_{t}$ and $\mathbf{X}_{t-p}$, adjusting for all intervening lags. The trace statistic,

$$
t_{r}=-T \sum_{j=r+1}^{n} \ln \left(1-\lambda_{j}\right), \quad 0 \leq r \leq n
$$

tests the null hypothesis that there are no more than $\mathrm{r}$ cointegrating vectors. For the null hypothesis of $r$ against the alternative of $r+1$ cointegrating vectors, we use the maximum eigenvalue statistic,

$$
\lambda_{r \mid r+1}=-T \ln \left(1-\lambda_{r+1}\right) .
$$

The eigenvectors $v_{1}, \ldots, v_{\mathrm{n}}$ associated with the eigenvalues $\lambda_{1} \geq \ldots \geq \lambda_{\mathrm{n}}$ are the sample estimates of the cointegrating vectors.

The cointegration test results are reported in Table 4. The lag parameter, $p$, is set to 3 , which gives insignificant Q-statistics, and thus, adequately accounts for the inter-temporal dynamics in the data (see Table 5). Both the trace and maximum eigenvalue statistics reject the hypothesis of no-cointegration but not the hypothesis of there is one cointegrating vector. That is, the output data are cointegrated with one cointegrating vector. The cointegration result implies that, even the individual output series wander randomly over time on their own, they are driven 
by common stochastic trends and, hence, have synchronous long-term movements. Despite the differences in output mixes, corporate cultures, and infrastructures, the Johansen test statistics indicate that the output series of China, Japan, and Korea share some common stochastic trends, move in tandem, and do not drift apart in the long run.

Table 4. Cointegration Test Results

\begin{tabular}{ccc}
\hline & Max Statistic & Trace Statistic \\
\cline { 2 - 3 }$=2$ & 1.14 & 1.14 \\
$\mathrm{r}=1$ & 13.59 & 14.73 \\
$\mathrm{r}=0$ & $37.55^{*}$ & $52.28^{*}$ \\
\hline
\end{tabular}

Note: The Johansen maximum eigenvalue test and trace test statistics are reported, respectively, under the headings "Max Statistic" and "Trace Statistic." The 5\% level significance is indicated by "**" (Cheung and Lai, 1993). The lag parameter is 3 . The estimated cointegrating vector is (1, $5.39,-2.90)$ with the China coefficient normalized to 1 . The chi-square test statistics for the significance of individual cointegrating coefficient estimates are, respectively, 23.32, 20.77, and 33.03. That is, each of the cointegrating coefficient estimates is significant.

The cointegration of output data may be viewed as a necessary condition for forming a currency union. If the output series are not cointegrated, they drift apart in the long run, and it is difficult to effectively manage the three economies using a common monetary policy and a common currency. Thus, the cointegration result, which implies the national output data are synchronous in the long run, is supportive of the concept of a currency union between China, Japan, and Korea.

\subsection{Vector Error Correction Model}

Since the GDP data are cointegrated, a vector error correction model (VECM) is used to examine the interactions between the output growth rates. The VECM is given by

$$
\Delta \mathbf{X}_{t}=\mu+\sum_{i=1}^{p} \Gamma_{i} \Delta \mathbf{X}_{t-i}+\alpha Z_{t-p-1}+\varepsilon_{t}
$$

where $\mu$ is a vector of constants, $Z_{t-p-1}$ is the error correction term given by $\hat{\beta}^{\prime} \mathbf{X}_{t-p-1}$, and $\hat{\beta}$ is the estimated cointegrating vector. The responses of output growth to short-term output movements are captured by the $\Gamma_{i}$ coefficient matrices. The $\alpha$ coefficient vector reveals the speed 
of adjustment to the error correction term, which measures deviations from the empirical longrun relationship.

Table 5. Vector Error Correction Models

\begin{tabular}{|c|c|c|c|}
\hline & China & Japan & Korea \\
\hline \multirow[t]{2}{*}{ Constant } & $0.040^{*}$ & -0.001 & 0.004 \\
\hline & $(8.729)$ & $(-0.095)$ & $(0.176)$ \\
\hline \multirow[t]{2}{*}{$E C T$} & $-0.051^{*}$ & -0.045 & 0.123 \\
\hline & $(-3.590)$ & $(-1.209)$ & $(1.717)$ \\
\hline \multirow[t]{2}{*}{$C H G D P(-1)$} & $-0.696^{* *}$ & -0.192 & 0.457 \\
\hline & $(-4.793)$ & $(-0.500)$ & $(0.623)$ \\
\hline \multirow[t]{2}{*}{$C H$ GDP(-2) } & $-0.591 *$ & 0.069 & 0.730 \\
\hline & $(-4.963)$ & $(0.219)$ & $(1.212)$ \\
\hline \multirow[t]{2}{*}{$C H G D P(-3)$} & $-0.597 *$ & -0.195 & -0.106 \\
\hline & $(-4.475)$ & $(-0.554)$ & $(-0.157)$ \\
\hline \multirow[t]{2}{*}{$J P G D P(-1)$} & $0.199^{* *}$ & $-0.692^{*}$ & 1. $178 * *$ \\
\hline & (1.787) & $(-2.359)$ & $(2.094)$ \\
\hline \multirow[t]{2}{*}{$J P G D P(-2)$} & 0.079 & $-0.724 *$ & $1.748^{*}$ \\
\hline & $(0.629)$ & $(-2.178)$ & $(2.745)$ \\
\hline \multirow[t]{2}{*}{$J P G D P(-3)$} & -0.065 & -0.314 & 2. $098^{*}$ \\
\hline & $(-0.491)$ & $(-0.899)$ & (3.135) \\
\hline \multirow[t]{2}{*}{$K O G D P(-1)$} & $0.139 *$ & 0.225 & 0.164 \\
\hline & $(2.252)$ & $(1.380)$ & $(0.526)$ \\
\hline \multirow[t]{2}{*}{$K O G D P(-2)$} & 0.045 & 0.056 & 0.018 \\
\hline & $(0.773)$ & $(0.366)$ & $(0.062)$ \\
\hline \multirow[t]{2}{*}{$K O G D P(-3)$} & 0.000 & 0.167 & $-0.558^{*}$ \\
\hline & $(0.024)$ & $(1.187)$ & $(-2.068)$ \\
\hline Adjusted - & 0.726 & 0.354 & 0.513 \\
\hline \multirow[t]{2}{*}{$Q(4)$} & 3.197 & 1.082 & 2.267 \\
\hline & $(0.525)$ & $(0.897)$ & $(0.687)$ \\
\hline \multirow[t]{2}{*}{$Q(8)$} & 5.425 & 8.672 & 4.904 \\
\hline & $(0.711)$ & $(0.371)$ & $(0.768)$ \\
\hline
\end{tabular}

Note: The estimates of the vector error correction model for the output data from China, Japan, and Korea are presented. Robust t-statistics are given in parentheses below the parameter 
estimates. "*" and "**" indicate significant at the 5\% and $10 \%$ level, respectively. ECT is the error correction term. $\mathrm{Q}(\mathrm{p})$ is the $\mathrm{Q}$-statistic calculated from the first $\mathrm{p}$ sample autocorrelations with the associated $\mathrm{p}$-value given in the parentheses underneath.

The estimates of (6) are reported in Table 5. As indicated by the diagnostic Q-statistics, the fitted models are adequate in the sense that the residual estimates display no significant serial correlation. The China equation has the highest adjusted R-squares, which is followed by the Korea equation and the Japan equation. A few observations are in order. First, the Chinese growth rate but not the other two is significantly affected by the error correction term. In the trivariate system, China is the only country adjusts to deviations from the empirical long-run output relationship. Using the Granger causality terminology in the VECM framework (Granger and Lin, 1995), Chinese output is caused by the other two economies in the long run. The result is consistent with the view that China is still at an early development stage and its growth is likely to be sensitive to the external environment. ${ }^{12}$ Japan and Korea are relatively matured economies and do not response to the error correction term.

The coefficient estimates of the lagged growth variables, which describe the short-run output interactions between these countries, display a clear pattern. The output variation is transmitted across borders mostly according to the perceived relative economic dominance: China is affected by lagged Japanese and Korean output growth rates, Korea is affected by lagged Japanese growth rates only, and Japan responds only to its own lagged growth. The own lagged growth effect is negative - indicative of some kinds of mean-reverting growth dynamics. The cross-country output effect, on the other hand, is predominately positive. The positive spillover effect is a potential source of synchronous movements in these economies.

Conceivably, a currency union arrangement can exploit the spillover effect and internalize the benefit.

Japan's strong economic influence is directly related to its size and to its massive foreign direct investments in Asia. Despite its recent economic troubles, Japan is still the most advanced economy in the region and is considered as one of the locomotives of the Asian and the world economy. Even though it is smaller, Korea has a relatively vibrant economy and considerable

12 The discussion in Section 2 underscores the linkages via trade and investment. China has evolved from a relatively autarkic economy with a trade-to-GDP ratio of 0.11 in 1979 to an economy with a ratio of 0.48 in 2002 . In 2002, China's trade-to-GDP ratio is larger than the Japan's one (0.19) and smaller than the Korea's one (0.66). Also, exports to Japan and Korea accounted for $20 \%$ of China's total exports. 
amount of foreign direct investments in China. The apparent absence of China effects is not surprising. As a new comer to the stage of the world economy, China is still at its early stage of economic development and exerts a relatively small impact on the other two economies. ${ }^{13}$

\subsection{Common Feature and Codependent Business Cycles}

For the usual conduct of monetary policy, short-run output fluctuations are an prominent concern. When shocks are asymmetric and national business cycles are asynchronous, a common currency and a common monetary policy are ineffectual in combating shocks to the countries and fine-tuning economic activities. Thus, business cycle synchronization has significant implications for a common single currency discussion. From the previous subsection, we know that the GDPs of China, Japan, and Korea share common long-run cycles. However, there is no direct evidence that these three countries share common business cycles. In this subsection, we directly test for the presence of common business cycles.

Output growth correlation patterns are usually employed to gauge cyclical variations in business cycles. Engle and Kozicki (1993) advocate the use of the common feature test to detect common serial correlations and, hence, common business cycle behavior. The intuition behind the common feature analysis is as follows. Suppose the elements of $\Delta \mathbf{X}_{\mathrm{t}}$ share a common temporal dynamics. Then, by forming an appropriate linear combination of $\Delta X_{i t}$ 's, we can eliminate the effect of the common component. Thus, the presence of a common cycle, which is routinely measured by serial correlation in the literature, implies the existence of a linear combination of $\Delta X_{i t}$ 's that is not correlated with the past information set.

Vahid and Engle (1993) devise a procedure to test for common serial correlation cycles in the presence of cointegration. The procedure amounts to finding the sample canonical correlations between $\Delta \mathbf{X}_{t}$ and $\mathbf{W}(p) \equiv\left(\Delta \mathbf{X}_{t-1}^{\prime}, \ldots, \Delta \mathbf{X}_{t-p}^{\prime}, Z_{t-1}\right)$, where $Z_{t-1}$ is the error correction term. The test statistic for the null hypothesis that there are at least $s$ cofeature vectors is given by

$$
C(p, s)=-(T-p-1) \sum_{j=1}^{s} \ln \left(1-\lambda_{j}\right)
$$

13 Though the data did not reveal the Chinese effects, it is conceived that both Japan and Korea are increasingly dependent on China for their exports (see, for example, Williams, 2002). 
where $\lambda_{j}$ is the $\mathrm{j}$-th smallest squared canonical correlations between $\Delta \mathbf{X}_{t}$ and $\mathbf{W}(p)$. The dimension (rank) of the cofeature space is the number of statistically zero squared canonical correlations. Under the null hypothesis, the statistic $C(p, s)$ has a $\chi^{2}$-distribution with $s^{2}+$ snp + $s r-s n$ degrees of freedom.

The concept of a common feature requires that the data respond to shocks simultaneously and are in similar phases throughout a business cycle. Specifically, for countries to share common feature business cycles, the entire time profiles of their reactions to common shocks have to be similar. If countries have different initial responses to a given shock, there will be no common feature. Because of country-specific factors including institutional structures and capital/labor input, shocks can initially propagate through countries at uneven speeds and countries can have dissimilar initial responses to shocks. Nonetheless, even with unequal initial responses, the countries can react fully and symmetrically to the shock in later periods. The common feature test will have low power to detect this type of common business cycles because it does not allow for dissimilar initial responses to shocks.

Vahid and Engle (1997) propose the codependence statistic to test for the presence of business cycles in which countries initially have different reactions to shocks but share common cyclical movement after the early phase. Technically, a system of time series is said to be codependent if impulse responses of the variables are collinear beyond a certain period. A codependent cycle allows the series to have different initial responses to a shock but requires them to share a common response pattern after the initial stage. The notion of codependence is a generalization of common feature, which requires the variables to have collinear impulse responses for all periods. In fact, a common serial correlation feature cycle is a codependent cycle with the initial period (that allows for differential responses) being an empty set. Without restricting the initial effects on the variables, the notion of codependent cycles makes it operationally feasible to model a general class of business cycles. The test statistic for the null hypothesis that there are at least $s$ codependent vectors after the k-th period is

$$
C(k, p, s)=-(T-p-1) \sum_{j=1}^{s} \ln \left\{1-\left[\lambda_{j}(k) / d_{j}(k)\right]\right\},
$$

where $\lambda_{\mathrm{n}}(k) \geq \ldots \geq \lambda_{1}(k)$ are the squared canonical correlations between $\Delta \mathbf{X}_{t}$ and $\mathbf{W}(\mathrm{k}, \mathrm{p}) \equiv$ $\left(\Delta \mathbf{X}_{t-k-1}^{\prime}, \ldots, \Delta \mathbf{X}_{t-k-p}^{\prime}, Z_{t-1}\right)$, and $d_{j}(k)$ is given by

$$
d_{j}(k)=1, \quad \text { for } k=0,
$$


and

$$
d_{j}(k)=1+2 \sum_{v=1}^{k} \rho_{v}\left(\alpha^{\prime} \Delta X_{t}\right) \rho_{v}\left(\gamma^{W}(k, p)\right) \quad \text { for } k \geq 1,
$$

where $\rho_{v}\left(y_{t}\right)$ is the sample autocorrelation of $y_{\mathrm{t}}$ at the $v$-th lag, $\alpha$ and $\gamma$ are the canonical variates corresponding to $\lambda_{j}(k)$. Note that when $k=0$, the codependence test statistic $C(k, p, s)$ is reduced to the common feature test statistic $C(0, p, s) \equiv C(p, s)$. Under the null hypothesis, the statistic $C(k, p, s)$ has a $\chi^{2}$-distribution with $s^{2}+s n p+s r-s n$ degrees of freedom.

The common feature and codependence test results are given in Table 6. The common feature test does not reject the hypothesis of $s=1$ but rejects both the hypotheses of $s=3$ and $s=$ 2. The evidence suggests the presence of one cofeature vector and, hence, common business cycles among China, Japan, and Korea. Thus, in addition to common long-term cyclical movements, the three largest Asian economies share common short-term business cycles. As argued earlier, the presence of common business cycles is a key precondition of a currency union.

On the presence of codependence, results in Table 6 show that, for $k=1$, the data reject the hypothesis of $s=3$ but not those of $s=1$ and $s=2$. Literally, the evidence is for the presence of two codependent vectors and, hence, for the presence of codependent business cycles. However, we know that a common feature is a special case of codependence, and one cofeature vector was reported. The codependence results should be properly interpreted as evidence of the presence of one codependent vector for common feature business cycles and one for codependent business cycles. That is, in addition to completely synchronized common business cycles, the countries share common cycles in which they have differential responses to a common shock in an initial state of three months. After the initial state, the national business cycles are synchronous. Apparently, the degree of diverse initial responses revealed in Table 6 does not represent a big negative factor for a currency union proposal. ${ }^{14}$ The findings reported in Table 6 are undeniably a positive evidence for a currency union in the region.

$14 \quad$ McKinnon and Schnabl (2003) use a different approach to assert that the business cycles of East Asia economies are highly synchronized. 
Table 6. Common Feature and Codependence Test Results

\begin{tabular}{|c|c|c|c|c|c|}
\hline \multicolumn{4}{|c|}{ Common Feature Test } & \multirow{2}{*}{$\begin{array}{c}\text { Co-Dependence Test } \\
\text { Statistic C }(p, k, s)\end{array}$} & \multirow[b]{2}{*}{ Degree of Freedom } \\
\hline Null & $\begin{array}{c}\text { Squared } \\
\text { Canonical Correlation } \\
\end{array}$ & Statistic C $(p, s)$ & $\begin{array}{c}\text { Squared } \\
\text { Canonical Correlation } \\
\end{array}$ & & \\
\hline$S=1$ & 0.329 & 10.390 & 0.154 & 3.359 & 8 \\
\hline$S=2$ & 0.532 & $30.117^{*}$ & 0.427 & 17.304 & 18 \\
\hline$S=3$ & 0.744 & $65.584^{*}$ & 0.940 & $75.308^{*}$ & 30 \\
\hline
\end{tabular}

Note: Under the null hypothesis, the common feature test statistic $C(p, s)$ and the codependence statistic $C(p, k, s)$ have an asymptotic $\chi^{2}$ distribution with $s^{2}+s n p+s r-s n$ degrees of freedom, where in this exercise $n=3, p=3$, and $r=1$. "** indicates significance at the $5 \%$ level. 


\section{Potential Output Loss}

The output synchronicity results in Section 4 indicate that China, Japan, and Korea are potential candidates of a currency union because their output data move closely together in both the long and short run. The commonality of output variations potentially reduces the costs of adopting a single currency and pursuing a common stabilization policy. While there are benefits

of forming a currency union, there are costs too. It is conceived that benefits come at the microeconomic level and are originated from, for example, the gain in economic efficiency, reduction in transaction costs, and elimination of foreign exchange uncertainty. On the other hand, costs are related to macroeconomic management. Joining a currency union implies the monetary authorities have to relinquish policy autonomy and lose the capacity to fine-tune the economy.

\subsection{The Model}

In this subsection, we use the Ghosh and Wolf (1994) setting to illustrate the output cost of relinquishing monetary policy autonomy to join a currency union. The model assumes nominal wage rigidity to establish the benefits of autonomous monetary policy. Before joining a currency union, individual countries use their own monetary policies to fine-tune their economies in the presence of adverse shocks to achieve full employment. However, under a currency union arrangement, a common monetary policy is used to combat a union-wise shock, which is a function of shocks to its member countries. Since the currency union shock is not necessary the same as individual shocks, the pursuant of a common policy does not necessarily achieve full employment in all member countries and, hence, induces the output cost of joining a currency union.

Consider the scenario before joining a currency union. Let a country's output be given by

$$
Q_{t}=e^{\theta_{t}} l_{t}^{\alpha},
$$

where $\theta_{t}$ is a productivity shock, $l_{t}$ is labor employed in period $t$, and $0<\alpha<1$ is the labor share. The real wage is equal to the marginal product of labor. The nominal wage rate, $w_{t}$, is downward sticky and is based on information available at t-1,

$$
\log \left(w_{t}\right)=\log \left(E_{t-1} p_{t}\right)+\log (\alpha)+E_{t-1} \theta_{t}+(\alpha-1) \log (\bar{l})
$$


where $p_{t}$ is the price level, and $E_{t-1}$ is the expectations operator based on information available at time $\mathrm{t}-1$. It is assumed that the wage is set (given the expected price and expected productivity shock) to clear the labor market; thus, $\bar{l}$ is the equilibrium employment level.

Since the nominal wage is only rigid downward, the wage rate adjusts to clear the market if the unexpected productivity shock $\varepsilon_{t}\left(\cong \theta_{t}-E_{t-1} \theta_{t}\right)$ is positive. However, if the unexpected productivity shock $\varepsilon_{t}$ is negative, the wage rate does not move down and the actual ex post labor demand $\left(l_{t}\right)$ is given by

$$
\log \left(p_{t}\right)+\theta_{t}+(\alpha-1) \log \left(l_{t}\right)=\log \left(w_{t}\right) .
$$

Note that $l_{t}$ does not represent the equilibrium employment level. If the country is not in a currency union, monetary policies can be used to offset the adverse shock and restore labor market equilibrium by setting the price at the level

$$
\log \left(p_{t}\right)-\log \left(E_{t-1} p_{t}\right)=-\varepsilon_{t} .
$$

In this case,

$$
\begin{aligned}
\log \left(p_{t}\right)+\theta_{t}+(\alpha-1) \log (\bar{l}) & =\log \left(w_{t}\right) \\
& =\log \left(E_{t-1} p_{t}\right)+E_{t-1} \theta_{t}+(\alpha-1) \log (\bar{l}) .
\end{aligned}
$$

Now suppose the country forms a currency union with another country. Let the productivity shock to the currency union be $\varepsilon_{t}^{c}$, which is a combination of shocks to the two member countries. Further, assume the currency union's monetary authorities pursue a stabilization policy similar to (13) and set the union's price level $\left(p_{t}^{c}\right)$ according to

$$
\log \left(p_{t}^{c}\right)-\log \left(E_{t-1} p_{t}^{c}\right)=-\varepsilon_{t}^{c} .
$$

When $\varepsilon_{t}<\varepsilon_{t}^{c}$, the policy (15) does not yield full employment for the country under consideration. From (10), (12) and (15), the country's output loss, in percentage term, is given by

$$
L_{t}=1-\exp \left[\left(\varepsilon_{t}-\varepsilon_{t}^{c}\right) \alpha /(1-\alpha)\right] .
$$

See Ghosh and Wolf (1994) for a detailed discussion of the model, interpretations, and caveats. In the following, equation (16) is used to evaluate the nations' output costs of forming a currency union. It should point out that (16) is quite simple and is meant to provide an initial estimate of the cost of joining a currency union 


\subsection{The Estimated Output Cost}

According to equation (16), the output loss of joining a currency union depends on three factors: the shock to the economy $\varepsilon_{t}$, the shock to the currency union $\varepsilon_{t}^{c}$, and the labor share $\alpha$. To check the robustness of our exercise, we consider $\varepsilon_{t}$ 's obtained from three alternative approaches. The vector error correction model in Section 4 is used to generate the first set of shocks. The Hodrick-Prescott filter gives the second set of shocks. The supply shocks constructed using the Blanchard-Quah method are the third candidate considered in this exercise.

The shock to the currency union $\varepsilon_{t}^{c}$ is defined in two alternative ways. First, we assume that the monetary authorities in the currency union stipulate the shock to the union as the GDPweighted average of individual country's shocks. Next, we assume the currency union shock is the simple average of shocks to individual countries. For simplicity, we label these two definitions of currency union shocks as the GDP-weighted average shock and the simple average shock hereafter. We also consider the value of the labor share parameter $\alpha$ in the range from 0.3 to 0.7 .

Table 7 presents the estimates of percentage output losses. A few observations are in order for the results based on the GDP-weighted average shock. First, as indicated by (16), a larger $\alpha$ parameter is associated with a higher percentage of output loss. Intuitively, the output loss in the model is due to the inability to restore the labor market equilibrium. Thus, a large labor share implies a large output loss, ceteris paribus. The labor share effect can be quite pronounced. In the case of Korea, when the shocks are computed from the vector error correction model, the output loss increases from $0.6 \%$ to $1.35 \%$ when $\alpha$ increases from 0.5 to 0.7 .

Second, the rankings of national output loss estimates are the same across the three shock-estimation methods. Korea always has the largest percentage output loss estimate while Japan has the least. The rankings appear consistent with the way the currency union shock is defined. Because Japan is the largest economy in the group and the currency union shock is defined as a GDP-weighted average shock, the stabilization policy will response more to shocks originated from Japan. Again, consider the case of $\alpha=0.7$ and the vector error correction model. The output loss estimates are $0.22 \%, 0.08 \%$, and $1.35 \%$ for China, Japan, and Korea, respectively. The Korean estimate is about 17 times larger than the Japanese one. 
Table 7. The Average Output Losses in Percentages

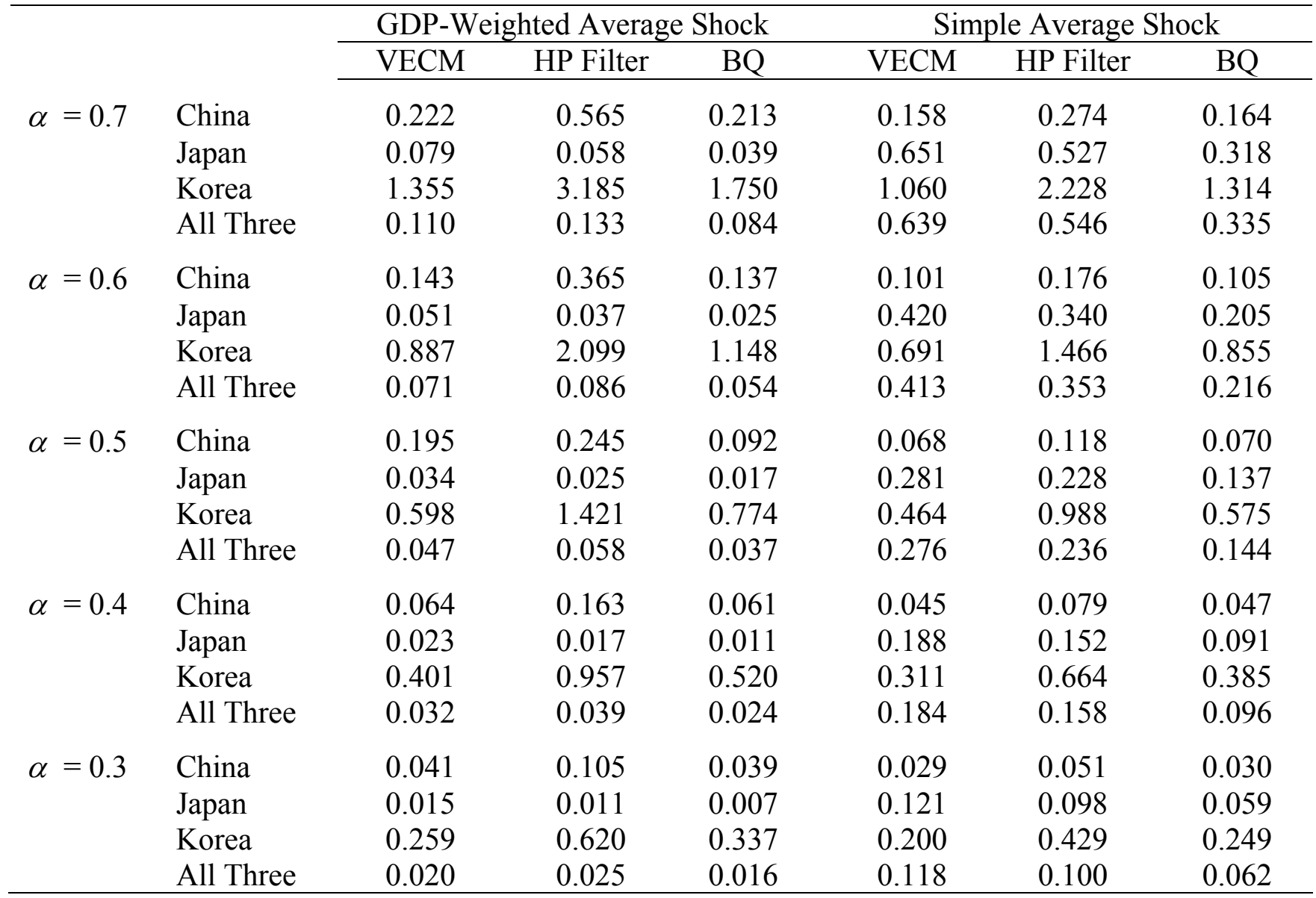

Note: The average percentage output losses estimated under the assumptions of the currency union shock is given by the GDP-weighted average and the simple average of shocks to its member countries are reported. The "All Three" rows give the losses for the three countries as a group. The "VECM" column gives the output losses derived from shocks estimated from the vector error correction model. The "HP Filter" column gives the output losses derived from shocks generated from the HP-Filter. The "BQ" column gives the output losses based on supply shocks estimated from the Blanchard-Quah method. " $\alpha$ " is the labor share.

Even for the simple average currency union shock, Korea tends to have the highest percentage output losses. That is, the large Korean loss is not entirely due to its weight in defining the currency union shock. Further, the choices of shock-estimation methods and labor share values have no implication for the relative ranking of national output loss estimates. A possible reason for the result is that shocks to Korea are less similar to those in the other two countries such that the term $\left(\varepsilon_{t}-\varepsilon_{t}^{c}\right)$ is always large for Korea. 
Third, the output loss estimate appears quite sensitive to the method used to extract the shocks. Among the three shock-estimation methods, the Hodrick-Prescott filter yields the largest output loss estimates for China and Korea, and the vector error correction model tends to give Japan a larger output loss estimate. The variation of loss estimates is quite wide. In the case $\alpha=$ 0.7, the Chinese estimates range from $0.21 \%$ (Blanchard-Quah method) to $0.57 \%$ (HodrickPrescott filter), the Japanese estimates from 0.04\% (Blanchard-Quah method) to $0.08 \%$ (vector error correction model), and the Korean estimates from $1.35 \%$ (vector error correction model) to $3.18 \%$ (Hodrick-Prescott filter). The results highlight the importance of the shock-estimation method in evaluating output losses of joining a currency union. ${ }^{15}$

Fourth, the percentage of output loss for the three economies as a group is reported in Table 7 under the row labeled "All Three." For the cases under consideration, the output loss of the group is less than $0.13 \%$ (Hodrick-Prescott filter and $\alpha=0.7$ ). Recall that the output loss is derived under the assumption that individual monetary authorities can perfectly fine-tune their economies and, thus, the output loss should be properly interpreted as an upper bound of potential losses. The loss appears small compare with some estimates of the potential benefits of a currency union. For example, in an earlier study (Commission of the European Communities, 1990), it is estimated that the cost savings for the European countries to adopt a single currency are between $0.3 \%$ to $0.4 \%$ of the aggregate GDP. The benefit of price convergence, which is a likely consequence of creating a currency union, estimated by Hufbauer et al. (2002) is 0.55\% of the world GDP. If a common currency for the three Asian countries generates a similar magnitude of savings, then the benefits of forming an Asian currency union will outweigh the estimated output loss.

While the potential gain may offset the potential loss in forming an Asian currency union, there is a re-distribution issue. As evidenced in the Table, the output loss of a small country can be quite high. At the same time, a small economy is likely to achieve a low level of cost savings from gain in economic efficiency and reduction in transaction costs. Thus, without an appropriate re-distribution scheme, a small economy may not elect to join the union because the cost for it to join the currency union can be higher than the benefit. Obviously, there are other

15 The result is comparable to the sensitivity of the estimated benefits from free trade derived from different specifications reported in, for example, Brown et al. (2002) and Scollay and Gilbert (2001). 
(economic and political) factors affecting the decision of joining a currency union. Nonetheless, our discussion offers one perspective to analyze the situation.

The output loss estimates based on the assumption that the currency union shock is the simple average of the shocks to its members are comparable to those based on the GDP-weighted average specification. Specifically, the effects of labor share parameter $\alpha$ and shock-estimation methods on the estimated output losses are qualitatively similar to those derived from the GDPweighted average shock. However, the use of the simple average shock as the policy target has significant implications for the rankings of output loss estimates. Similar to the previous case, Korea still has the highest output loss estimates. However, in the current case China, instead of Japan, has the lowest loss estimates. Further, the Japanese output loss estimates under the simple average shock are higher than those under the GDP-weighted average shock while the opposite is true for the other two countries.

For the three countries as a group, the simple average shock yields output loss estimates that are unambiguously higher than the GDP-weighted average shock does. Indeed, the output loss can go above $0.5 \%$ of the group output ( $\alpha=0.7$ and vector error correction model). The results strongly suggest that the policy leaning towards the simple average shock, rather than the GDP-weighted average one, leads to a higher level of aggregate output loss. Nonetheless, it is conceivable that, in the absence of re-distribution of gains and losses, Japan with the largest economy in the group would prefer the policy abating the GDP-weighted average shock while the two other countries would favor the one that focuses on the simple average shock.

The output losses in US dollars are presented in the Appendix. Comparing the output losses under two different types of currency union shocks, it is obvious that the policy target of the simple average shock imposes a heavier output cost on the three nations as group than the one based on the GDP-weighted average shock. The Japanese output loss under the simple average shock alternative is substantially larger than that under the GDP-weighted average shock. In fact, for all the cases under consideration, Japan has the incentive to pay off the other two countries to reach the policy target of managing the GDP-weighted average shock. Thus, given the relative output gains and losses under these two types of currency union shocks, it is plausible for the common monetary authorities to select the GDP-weighted average shock as the policy target if the countries can compromise and reach a mutually agreeable re-distribution scheme. 
Table 7 contains output loss estimates for a range of labor share values. Nevertheless, it is instructive to consider the losses corresponding to some "reasonable" estimates of labor shares. To this end, we adopt the 1993-1996 labor share figures from Harrison (2002) and calculate the corresponding output losses. ${ }^{16}$ Specifically, the labor share parameter is set to 0.36 for China, 0.59 for Japan, and 0.49 for Korea.

Table 8 presents percentage output losses for specific labor share figures. The estimated loss ranges from $0.038 \%$ to $0.138 \%$ for China, from $0.24 \%$ to $0.403 \%$ for Japan, from $0.446 \%$ to $1.367 \%$ for Korea, and from $0.041 \%$ to $0.39 \%$ for the three countries as a group. Again, the group loss is much smaller when the GDP-weighted average shock, rather than the simple average shock, is considered. Indeed, under the GDP-weighted average shock, the output loss for the group is no larger than $0.073 \%$, which is much smaller than the possible gains from using a common currency reported in Commission of the European Communities (1990) or from price convergence (Hufbauer et al., 2002). The corresponding losses in US dollar values reported in the Appendix suggested that, with an appropriate redistribution scheme, the countries should select the GDP-weighted average shock as the policy target of the common monetary authorities.

Table 8. The Average Output Losses in Percentages for Specific Labor Shares

\begin{tabular}{lccccccc}
\hline & \multicolumn{2}{c}{ GDP-Weighted Average Shock } & & \multicolumn{3}{c}{ Simple Average Shock } \\
\cline { 2 - 3 } & $\underline{\text { VECM }}$ & $\underline{\text { HP Filter }}$ & $\underline{\text { BQ }}$ & & $\underline{\text { VECM }}$ & $\underline{\text { HP Filter }}$ & $\underline{\text { BQ }}$ \\
China & 0.054 & 0.138 & 0.052 & & 0.038 & 0.066 & 0.039 \\
Japan & 0.049 & 0.036 & 0.024 & & 0.403 & 0.327 & 0.196 \\
Korea & 0.575 & 1.367 & 0.745 & & 0.446 & 0.950 & 0.553 \\
All Three & 0.059 & 0.063 & 0.041 & & 0.390 & 0.327 & 0.199 \\
\hline
\end{tabular}

Note: The estimated average output losses in percentages are computed based on the labor share values: China $=0.36$, Japan $=0.59$, and Korea $=0.49$. The "GDP-Weighted Average Shock" and the "Simple Average Shock" columns give the output losses assuming the currency union monetary authorities respond, respectively, to the GDP-weighted average and the simple average of shocks to its member countries. The "All Three" rows give the losses for the three countries as a group. The "VECM" column gives the output losses derived from shocks estimated from the vector error correction model. The "HP Filter" column gives the output losses derived from shocks generated from the HP-Filter. The "BQ" column gives the output losses based on supply shocks estimated from the Blanchard-Quah method.

16 Since the China figure is not available, we assume China is a member of Harrison's "bottom-middle" income group. 


\section{Concluding Remarks}

In this exercise, we adopt an output perspective to assess the prospect for China, Japan, and Korea to form a currency union. It is found that the three countries have synchronous output movements at both long-run and short-term horizons. Further, the estimated output loss is likely to be less than the potential benefit from forming a currency union. It is also noted that the three countries have considerably intensified their trade and investment interactions since the 1990s. These results are supportive of the idea that China, Japan, and Korea should joint forces to form a currency union and promote their common economic interests. ${ }^{17}$ The positive inference of an Asian currency union is complementary to some existing studies based on different methodologies. $^{18}$

Even though our exercise attempts to offer some insight on the cost of China, Japan, and Korea to form a currency union, the analysis is far from complete. As discussed in Section 5, the macro model is rather simplistic, and the results are sensitive to, for example, the method used to estimate shocks to the economy. ${ }^{19}$ It is fair to state that the estimates are not definitive measures of output losses and should not be taken literally. Instead, one should emphasize the sensitivity of the results to, say, the shock estimation method and the definition of the currency union shock. The sensitivity has significant implications for estimating costs and devising policies in the process of formulating a currency union.

An additional complication is the self-validation nature of an exchange rate regime choice. The implementation of a currency union can induce structural changes that facilitate integration and increase the strength of common business cycles (Corestti and Pesenti, 2002; Frankel and Rose, 1998; Engel and Rose, 2002). The endogeneity of a currency union criterion further complicates the task of estimating costs and benefits. The recent European Union experience also indicates some potential issues on evaluating the costs and benefits of adopting a common currency. For instance, the "imbalance" growth phenomenon - the large countries experience slow growth and small economies experience high growth - is quite unexpected

17 One caveat is that the empirical results are derived from existing data. Given the rapid developments in these countries; especially in China, the future can look very different from what can be inferred from these empirical results.

18 See, for example, Bayoumi and Mauro (199), Eichengreen and Bayoumi (1999) and Ng (2002).

19 The benefits of forming a currency union are not considered in the current exercise. Further, the analysis considers neither the implications of industry-specific shocks nor the cost of resource re-allocation between sectors as a result of joining a currency union. Future analyses of the desirability of an Asian currency union should consider the benefit factors together with other possible costs. 
before the adoption of the Euro. It creates some tensions in setting the common monetary policy for the union.

It is unrealistic to assume the path to economic integration of China, Japan, and Korea is without impediments. The legacies of war, occupation, and communism remain a reality among the populations of these countries. A consequence of these antagonisms is the aversion to (potential) regional hegemony. Also, the cost of adjustment represents another challenge to economic integration. China, Japan, and Korea are at different stages of economic development. While the difference can lead to huge potential gains from trade and integration, it also creates serious problems when these countries have to adjust to external competition. Even without formal steps toward integration, ongoing adjustment to increased import penetration and competition in third markets has already resulted in some political resistance to deeper integration. For instance, agricultural trade is a contentious issue between China and Japan and, to a lesser extent, between China and Korea. Korean products, on the other hand, constitute more than $3 / 4^{\text {th }}$ of anti-dumping cases investigated by China. ${ }^{20}$ Of course, there are concerns that the growing Chinese production capacity will hollow out the manufacturing sectors in other countries and absorb foreign direct investment at the expense of other nations.

There are both economic and non-economic reasons that the tri-lateral economic cooperation may run into obstacles. However, recent developments were quite encouraging. For instance, China's willingness to foster trade and economic interactions with her neighboring economies is a positive sign. In the process, China presents its growing and booming economy as a benefit and an opportunity rather than a threat to its neighbors. Further, China, Japan, and Korea are quite active in promoting and conducting bilateral and multilateral negotiations on trade and financial issues. In addition, the rising trend of regionalism (NAFTA and EU, for example), the shadow of the 1997 financial crisis, and the increasing importance of intra-regional trade still provide incentives to institutionalize the co-operative economic relationship among the Asian countries. It is perceived that the process of economic integration will be long and involved despite the bright promise of closer economic cooperation.

20 See the Korea Times (2003). Between November 1996 and July 2003, 18 of the 23 cases investigated by China are related to Korean products. 


\section{References}

Baxter, Marianne and Alan C. Stockman, 1989, "Business Cycles and the Exchange-Rate Regime: Some International Evidence,” Journal of Monetary Economics 23, 377-400.

Bayoumi, Tamim and Barry J. Eichengreen, 1994, "One Money or Many? Analyzing the Prospects of Monetary Unification in Various Parts of the World," Princeton Studies in International Finance No. 76.

Bayoumi, Tamim and Paolo Mauro, 1999, “The Suitability of ASEAN for a Regional Currency Arrangement," IMF Working Paper 99/162.

Blanchard, Oliver J. and Danny Quah, 1989, “The Dynamic Effects of Demand and Supply Disturbances," American Economic Review 79, 655-673.

Brown, Drusilla K., Alan V. Deardorff and Robert M. Stern, 2002, "CGE Modeling and Analysis of Multilateral and Regional negotiating Options," in Robert M. Stern (editor), Issues and options for U.S.-Japan trade policies, 23- 65, Ann Arbor: University of Michigan Press.

Cabinet Office, Government of Japan, 2002, “Annual Report on the Japanese Economy and Public Finance, 2001-2002," http://www5.cao.go.jp/zenbun/wp-e/wp-je02/wp-je0200301.html.

Canova, Fabio, 1998, "Detrending and Business Cycle Facts," Journal of Monetary Economics 41, 475-512.

Cheung, Yin-Wong and Kon S. Lai, 1993, “Finite Sample Sizes of Johansen's Likelihood Ratio Tests for Cointegration," Oxford Bulletin of Economics and Statistics 55, 313-328.

Cheung, Yin-Wong and Kon S. Lai, 1995, "Lag Order and Critical Values for the Augmented Dickey-Fuller Test,” Journal of Business \& Economic Statistics 13, 277-280.

Cho, Hung-Guk, 2000, "The Trade Between China, Japan, Korea and Southeast Asia in the 14th Century Through the 17th Century Period," International Area Review 3, 67-107.

Commission of the European Communities, 1990, "One Market, One Money," European Economy 44, Office for Official Publications of the European Communities.

Corestti, Giancarlo, Paolo Pesenti, 2002, "Self-Validating Optimum Currency Areas," manuscript presented in the 2002 SCIII conference, UCSC.

De Grauwe, Paul, 2000, The Economics of Monetary Union, 4th ed., New York: Oxford University Press. 
Eichengreen, Barry J. and Tamim Bayoumi, 1999, "Is Asia an Optimum Currency Area? Can It Become One? Regional, Global and Historical Perspectives on Asian Monetary Relations," in Stefan Collignon, Jean Pisani-Ferry and Yung Chul Park (eds.), Exchange Rate Policies in Emerging Asian Countries, 347-366, London and New York: Routledge.

Eichengreen, Barry J. 2001, "Hanging together? On Monetary and Financial Cooperation in Asia," manuscript, UC Berkeley.

Eijffinger, Sylvester C.W. and Jakob de Haan , 2000, European monetary and fiscal policy, New York: Oxford University Press.

Engel, Charles and Andrew K. Rose 2002, "Currency Unions and International Integration," Journal of Money Credit and Banking 34, 1067-1089.

Engle, Robert. F. and Susan Kozicki, 1993, "Testing for Common Features," Journal of Business and Economics Statistics 11, 369-379.

Frankel, Jeffrey A. and Andrew K. Rose 1998, "The Endogeneity of the Optimum Currency Area Criteria," Economic Journal 108, 1009-1025.

Ghosh, Atish R. and Holger C. Wolf, 1994, "How Many Monies? A Genetic Approach to Finding Optimum Currency Areas,” NBER Working Paper\# 4805.

Granger, Clive W.J. and Jin-Lung Lin, 1995, "Causality in the Long Run," Econometric Theory $11,530-536$.

Harrison, Ann E., 2002, "Has Globalization Eroded Labor's Shares? Some Cross-Country Evidence," manuscript, UC Berkeley.

Harvey, A.C. and A. Jaeger, 1993, "Detrending, Stylized Facts and the Business Cycle," Journal of Applied Econometrics 8, 231-247.

Hernandez, Leonardo and Peter Montiel, 2002, "Post-Crisis Exchange Rate Policy in Five Asian Countries: Filling in the 'Hollow Middle'?" IMF Working Paper 01/170.

Hufbauer, Gary C., Erika Wada and Tony Warren, 2002, The Benefits of Price Convergence: Speculative Calculations, Policy Analyses in International Economics 63, Washington: Institute for International Economics.

Johansen, Soren, 1991, "Estimation and Hypothesis Testing of Cointegration Vectors in Gaussian Vector Autoregressive Models," Econometrica 59, 1551-1581. 
Johansen, Soren and Katarina Juselius, 1990, "Maximum Likelihood Estimation and Inference on Cointegration - with Applications to the Demand for Money," Oxford Bulletin of Economics and Statistics 52, 169-210.

Lafrance, Robert and Pierre St-Amant, 1999, "Optimum Currency Areas: A Review of the Recent Literature," Bank of Canada Working Paper 99-16.

Lee, Jong-Wha, Yung Chul Park and Kwanho Shin, "A Currency Union in East Asia," manuscript, Korea University.

McKinnon, Ronald I., 2001, "Optimum Currency Areas and Key Currencies: Mundell I versus Mundell II," manuscript, Stanford University.

McKinnon, Ronald I. and Gunther Schnabl, 2003, "Synchronized Business Cycles in East Asia and Fluctuations in the Yen/Dollar Exchange Rate," The World Economy 26, 1067-1088.

Mundell, Robert A., 1961, "A Theory of Optimum Currency Areas," American Economic Review 51, 657-665.

Mundell, Robert A., 1973, "Uncommon Arguments for Common Currencies," in H.G. Johnson andA.K. Swoboda, The Economics of Common Currencies, 114-32 Allen and Unwin.

National Institute for Research Advancement of Japan, 2002, "Report and Joint Policy Recommendations on Strengthening Economic Cooperation among China, Japan and Korea in 2002," presented at the trilateral summit meeting held in Phnom Penh on November 4, 2002, http://www.nira.go.jp/newse/paper/joint2/report.html.

Nam, Sang-yirl, 2003, Trade Structure and Complementarity Among APEC Member Economies, APEC Study Series 03-01, Korea: KIEP.

Ng, Thiam Hee, 2002, 'Should the Southeast Asian Countries form a Currency Union?' The Developing Economies 40, 113-34.

Schott, Jeffrey J. and Ben Goodrich, 2001, "Economic Integration in Northeast Asia," presented at the $2001 \mathrm{KIEP} / \mathrm{KEI} / \mathrm{CKS}$ conference, The Challenges of Reconciliation and Reform in Korea, Los Angeles, California.

Scollay, Robert and John P. Gilbert, 2001, New Regional Trading Arrangement in the Asia Pacific, Policy Analyses in International Economics 63, Washington: Institute for International Economics.

Vahid, Farshid and RRobert F. Engle, 1993, "Common Trends and Common Cycles," Journal of Applied Econometrics 8, 341-360. 
Vahid, Farshid and Robert F. Engle, 1997, "Codependent Cycles," Journal of Econometrics 80, 199-221.

Williams, M., 2002, “A Japanese Recovery Reliant on China,” Wall Street Journal October 25, 2002.

Wyplosz, Charles, 2002, “A Monetary Union in Asia? Some European Lessons," in David Gruen and John Simon (eds.), Future Directions for Monetary Policies in East Asia, Reserve Bank of Australia, 124-155. 


\section{Appendix: The Estimated Output Losses in US Dollars}

Table A1. The Output Losses in US Dollars (Billions)

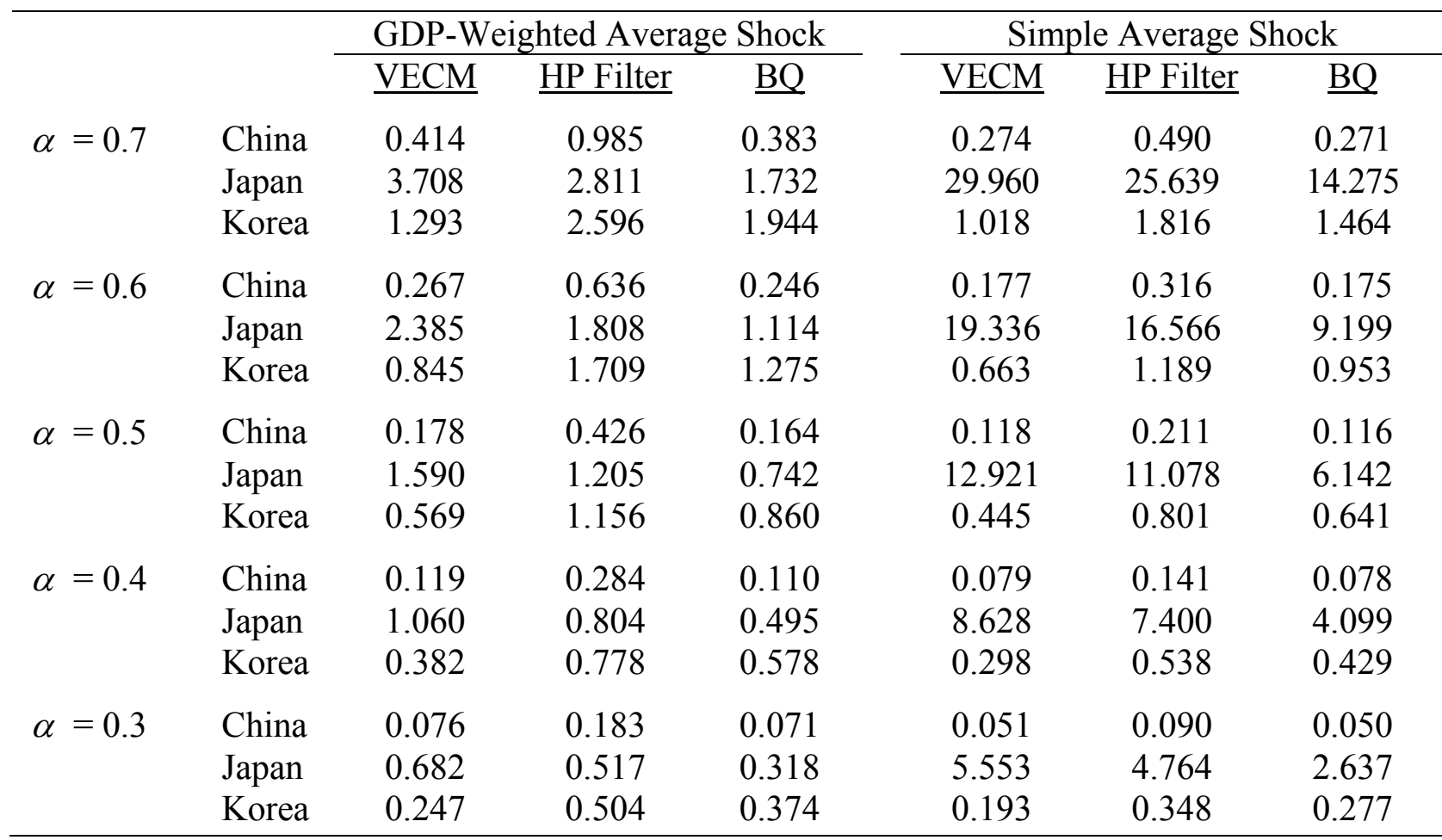

Note: The estimated average output losses in billions of US dollars are reported under the assumptions that the currency union shock is given by the GDP-weighted average and the simple average of the shocks to its member countries. The "VECM" column gives the output losses derived from shocks estimated from the vector error correction model. The "HP Filter" column gives the output losses derived from shocks generated from the HP-Filter. The "BQ" column gives the output losses based on supply shocks estimated from the Blanchard-Quah method. " $\alpha$ ” is the labor share. 
Table A2. The Values of Output Losses (US Dollars, Billions) for Specific Labor Shares

\begin{tabular}{lccccccc}
\hline & \multicolumn{3}{c}{ GDP-Weighted Average Shock } & & \multicolumn{3}{c}{ Simple Average Shock } \\
\cline { 2 - 3 } \cline { 7 - 8 } & $\underline{\text { VECM }}$ & $\underline{\text { HP Filter }}$ & $\underline{\text { BQ }}$ & & $\underline{\text { VECM }}$ & $\underline{\text { HP Filter }}$ & $\underline{\text { BQ }}$ \\
China & 0.100 & 0.240 & 0.093 & & 0.066 & 0.119 & 0.066 \\
Japan & 2.288 & 1.734 & 1.068 & & 18.555 & 15.898 & 8.827 \\
Korea & 0.547 & 1.112 & 0.827 & & 0.428 & 0.770 & 0.616 \\
\hline
\end{tabular}

Note: The estimated average output losses in billions of US dollars are computed based on the labor share values: China $=0.36$, Japan $=0.59$, and Korea $=0.49$. The "GDP-Weighted Average Shock" and the "Simple Average Shock" columns give the output losses assuming the currency union monetary authorities respond, respectively, to the GDP-weighted average and the simple average of shocks to its member countries. The "VECM" column gives the output losses derived from shocks estimated from the vector error correction model. The "HP Filter" column gives the output losses derived from shocks generated from the HP-Filter. The "BQ" column gives the output losses based on supply shocks estimated from the Blanchard-Quah method. 


\section{CESifo Working Paper Series}

(for full list see www.cesifo.de)

1186 Jean-Pierre Ponssard, Rent Dissipation in Repeated Entry Games: Some New Results, May 2004

1187 Pablo Arocena, Privatisation Policy in Spain: Stuck Between Liberalisation and the Protection of Nationals' Interests, May 2004

1188 Günter Knieps, Privatisation of Network Industries in Germany: A Disaggregated Approach, May 2004

1189 Robert J. Gary-Bobo and Alain Trannoy, Efficient Tuition Fees, Examinations, and Subsidies, May 2004

1190 Saku Aura and Gregory D. Hess, What's in a Name?, May 2004

1191 Sjur Didrik Flåm and Yuri Ermoliev, Investment Uncertainty, and Production Games, May 2004

1192 Yin-Wong Cheung and Jude Yuen, The Suitability of a Greater China Currency Union, May 2004

1193 Inés Macho-Stadler and David Pérez-Castrillo, Optimal Enforcement Policy and Firms' Emissions and Compliance with Environmental Taxes, May 2004

1194 Paul De Grauwe and Marianna Grimaldi, Bubbles and Crashes in a Behavioural Finance Model, May 2004

1195 Michel Berne and Gérard Pogorel, Privatization Experiences in France, May 2004

1196 Andrea Galeotti and José Luis Moraga-González, A Model of Strategic Targeted Advertising, May 2004

1197 Hans Gersbach and Hans Haller, When Inefficiency Begets Efficiency, May 2004

1198 Saku Aura, Estate and Capital Gains Taxation: Efficiency and Political Economy Consideration, May 2004

1199 Sandra Waller and Jakob de Haan, Credibility and Transparency of Central Banks: New Results Based on Ifo's World Economicy Survey, May 2004

1200 Henk C. Kranendonk, Jan Bonenkamp, and Johan P. Verbruggen, A Leading Indicator for the Dutch Economy - Methodological and Empirical Revision of the CPB System, May 2004 
1201 Michael Ehrmann, Firm Size and Monetary Policy Transmission - Evidence from German Business Survey Data, May 2004

1202 Thomas A. Knetsch, Evaluating the German Inventory Cycle - Using Data from the Ifo Business Survey, May 2004

1203 Stefan Mittnik and Peter Zadrozny, Forecasting Quarterly German GDP at Monthly Intervals Using Monthly IFO Business Conditions Data, May 2004

1204 Elmer Sterken, The Role of the IFO Business Climate Indicator and Asset Prices in German Monetary Policy, May 2004

1205 Jan Jacobs and Jan-Egbert Sturm, Do Ifo Indicators Help Explain Revisions in German Industrial Production?, May 2004

1206 Ulrich Woitek, Real Wages and Business Cycle Asymmetries, May 2004

1207 Burkhard Heer and Alfred Maußner, Computation of Business Cycle Models: A Comparison of Numerical Methods, June 2004

1208 Costas Hadjiyiannis, Panos Hatzipanayotou, and Michael S. Michael, Pollution and Capital Tax Competition within a Regional Block, June 2004

1209 Stephan Klasen and Thorsten Nestmann, Population, Population Density, and Technological Change, June 2004

1210 Wolfgang Ochel, Welfare Time Limits in the United States - Experiences with a New Welfare-to-Work Approach, June 2004

1211 Luis H. R. Alvarez and Erkki Koskela, Taxation and Rotation Age under Stochastic Forest Stand Value, June 2004

1212 Bernard M. S. van Praag, The Connexion Between Old and New Approaches to Financial Satisfaction, June 2004

1213 Hendrik Hakenes and Martin Peitz, Selling Reputation When Going out of Business, June 2004

1214 Heikki Oksanen, Public Pensions in the National Accounts and Public Finance Targets, June 2004

1215 Ernst Fehr, Alexander Klein, and Klaus M. Schmidt, Contracts, Fairness, and Incentives, June 2004

1216 Amihai Glazer, Vesa Kanniainen, and Panu Poutvaara, Initial Luck, Status-Seeking and Snowballs Lead to Corporate Success and Failure, June 2004

1217 Bum J. Kim and Harris Schlesinger, Adverse Selection in an Insurance Market with Government-Guaranteed Subsistence Levels, June 2004 
1218 Armin Falk, Charitable Giving as a Gift Exchange - Evidence from a Field Experiment, June 2004

1219 Rainer Niemann, Asymmetric Taxation and Cross-Border Investment Decisions, June 2004

1220 Christian Holzner, Volker Meier, and Martin Werding, Time Limits on Welfare Use under Involuntary Unemployment, June 2004

1221 Michiel Evers, Ruud A. de Mooij, and Herman R. J. Vollebergh, Tax Competition under Minimum Rates: The Case of European Diesel Excises, June 2004

1222 S. Brock Blomberg and Gregory D. Hess, How Much Does Violence Tax Trade?, June 2004

1223 Josse Delfgaauw and Robert Dur, Incentives and Workers' Motivation in the Public Sector, June 2004

1224 Paul De Grauwe and Cláudia Costa Storti, The Effects of Monetary Policy: A MetaAnalysis, June 2004

1225 Volker Grossmann, How to Promote R\&D-based Growth? Public Education Expenditure on Scientists and Engineers versus R\&D Subsidies, June 2004

1226 Bart Cockx and Jean Ries, The Exhaustion of Unemployment Benefits in Belgium. Does it Enhance the Probability of Employment?, June 2004

1227 Bertil Holmlund, Sickness Absence and Search Unemployment, June 2004

1228 Klaas J. Beniers and Robert Dur, Politicians' Motivation, Political Culture, and Electoral Competition, June 2004

1229 M. Hashem Pesaran, General Diagnostic Tests for Cross Section Dependence in Panels, July 2004

1230 Wladimir Raymond, Pierre Mohnen, Franz Palm, and Sybrand Schim van der Loeff, An Empirically-Based Taxonomy of Dutch Manufacturing: Innovation Policy Implications, July 2004

1231 Stefan Homburg, A New Approach to Optimal Commodity Taxation, July 2004

1232 Lorenzo Cappellari and Stephen P. Jenkins, Modelling Low Pay Transition Probabilities, Accounting for Panel Attrition, Non-Response, and Initial Conditions, July 2004

1233 Cheng Hsiao and M. Hashem Pesaran, Random Coefficient Panel Data Models, July 2004

1234 Frederick van der Ploeg, The Welfare State, Redistribution and the Economy, Reciprocal Altruism, Consumer Rivalry and Second Best, July 2004 
1235 Thomas Fuchs and Ludger Woessmann, What Accounts for International Differences in Student Performance? A Re-Examination Using PISA Data, July 2004

1236 Pascalis Raimondos-Møller and Alan D. Woodland, Measuring Tax Efficiency: A Tax Optimality Index, July 2004

1237 M. Hashem Pesaran, Davide Pettenuzzo, and Allan Timmermann, Forecasting Time Series Subject to Multiple Structural Breaks, July 2004

1238 Panu Poutvaara and Andreas Wagener, The Invisible Hand Plays Dice: Eventualities in Religious Markets, July 2004

1239 Eckhard Janeba, Moral Federalism, July 2004

1240 Robert S. Chirinko, Steven M. Fazzari, and Andrew P. Meyer, That Elusive Elasticity: A Long-Panel Approach to Estimating the Capital-Labor Substitution Elasticity, July 2004

1241 Hans Jarle Kind, Karen Helene Midelfart, Guttorm Schjelderup, Corporate Tax Systems, Multinational Enterprises, and Economic Integration, July 2004

1242 Vankatesh Bala and Ngo Van Long, International Trade and Cultural Diversity: A Model of Preference Selection, July 2004

1243 Wolfgang Eggert and Alfons J. Weichenrieder, On the Economics of Bottle Deposits, July 2004

1244 Sören Blomquist and Vidar Christiansen, Taxation and Heterogeneous Preferences, July 2004

1245 Rafael Lalive and Alois Stutzer, Approval of Equal Rights and Gender Differences in Well-Being, July 2004

1246 Paolo M. Panteghini, Wide vs. Narrow Tax Bases under Optimal Investment Timing, July 2004

1247 Marika Karanassou, Hector Sala, and Dennis J. Snower, Unemployment in the European Union: Institutions, Prices, and Growth, July 2004

1248 Engin Dalgic and Ngo Van Long, Corrupt Local Government as Resource Farmers: The Helping Hand and the Grabbing Hand, July 2004

1249 Francesco Giavazzi and Guido Tabellini, Economic and Political Liberalizations, July 2004

1250 Yin-Wong Cheung and Jude Yuen, An Output Perspective on a Northeast Asia Currency Union, August 2004 